\title{
Spirituality through the Lens of Students in Higher Education
}

\author{
Al Fuertes ${ }^{1, *(\mathbb{D})}$ and Kelley Dugan ${ }^{2}$ \\ 1 School of Integrative Studies, George Mason University, Fairfax, VA 22030, USA \\ 2 Carroll School of Management, Boston College, Newton, MA 02467-3809, USA; dugankk@bc.edu \\ * Correspondence: afuertes@gmu.edu
}

check for

updates

Citation: Fuertes, Al, and Kelley Dugan. 2021. Spirituality through the Lens of Students in Higher Education. Religions 12: 924. https://doi.org/ $10.3390 /$ rel12110924

Academic Editor: Hans Zollner

Received: 2 August 2021

Accepted: 18 October 2021

Published: 22 October 2021

Publisher's Note: MDPI stays neutral with regard to jurisdictional claims in published maps and institutional affiliations.

Copyright: (c) 2021 by the authors. Licensee MDPI, Basel, Switzerland. This article is an open access article distributed under the terms and conditions of the Creative Commons Attribution (CC BY) license (https:// creativecommons.org/licenses/by/ $4.0 /)$.

\begin{abstract}
Spirituality is an elusive concept to articulate. Not only do people define it in different ways, but all definitions somehow seem to be incomplete. In this article, eighty-eight undergraduate and graduate students from George Mason University (GMU) participated in a study to define spirituality within the context of higher education. Results of the study suggest the following themecategories. First, spirituality is an abstract reality, which is difficult to define. Second, spirituality is a moral compass, giving direction and meaning to people; and third, spirituality and religion are not the same, but they are interrelated. Since spirituality is a fluid concept that is unique from person to person, the article recommends that institutions of higher education need to incorporate into curricula mechanisms that provide students creative expressions of learning that are experiential, critical, and reflective, including opportunities that enable students to grow and develop holistically, which includes the spiritual aspect of growth, through open spaces of conversation and dialogue, and experiential learning such as community immersion and cross-cultural exchange programs as these will help cultivate and nurture their interests and aspirations, thereby, enabling them to develop meaning and purpose in life.
\end{abstract}

Keywords: spirituality; religion; George Mason University; meaning-making; unique; abstract reality; moral compass; conceptions; college students; higher education

\section{Introduction}

The U.S. News \& World Report 2021 Best Colleges lists George Mason University $(\mathrm{GMU})^{1}$ as the top-ranked public university in Virginia for ethnic diversity and 15th nationally (US News \& World Report Best Colleges 2021). Students come from various faith traditions, including agnosticism, atheism, and those who do not affiliate with any established religion across the world. This diversity has fostered a community with vast ideologies and cultural experiences that create a dynamic learning environment both inside and out of the classroom. One discussion piece, however, that is not as frequently spoken about is spirituality. Perhaps the prior silence on the topic of spirituality in the academe, including professional practice is due not only to the difficulty of defining spirituality but also to the ambivalence of many who work in an academic world that has emphasized rationality and the scientific method for most of the twentieth century (Tisdell 2003, p. 25).

Spirituality is an elusive topic to articulate (Harris 2007, p. 264). Not only do people define it in different ways, but all definitions somehow seem to be incomplete (Tisdell 2003, p. 25). Murgia et al. (Murgia et al. 2020, p. 1328) call it amorphous which is, conceptually stimulating, but difficult to define. There is a lack of consensus in defining spirituality, which pervades the educational, academic, and religious worlds as well as society as a whole (Harris 2007, p. 264). In his experience working in higher education, Chickering writes,

When we gather with colleagues to discuss "spirituality in higher education" - a problematic, many-faceted arena-we find ourselves using diverse terms that vary, depending on our personal and professional backgrounds. Persons anchored in various religious traditions and from faith-based institutions are typically accustomed to, and comfortable 
with, the language of spirituality. But for others, that language carries baggage from the worlds of established religions and churches with which they do not identify. They do not want to be understood to endorse anything that hints at proselytizing or indoctrination. Atheists, agnostics, and persons with strong humanistic orientations find that words like authenticity, purpose, meaning, integrity, wisdom, and values express their concerns. For these persons character development and moral development are legitimate concerns for higher education, but "spiritual growth" raises red flags. (Chickering 2006, p. 2)

Chickering's comments resonate with the results of the 2003 UCLA initiated pilot survey of 3680 third-year undergraduates attending forty-six institutions across the country, where students who completed the survey said that their professors "never" provide opportunities to discuss the meaning and purpose of life. Similarly, nearly two-thirds said that their professors "never" encourage discussion of religious or spiritual matters (Lindholm 2007, p. 11). Although the study was conducted several years ago, the findings remain relevant as today's academic institutions find ways addressing students' interests and needs on spiritual matters.

In their article, "Why is it so hard to talk about Spirituality?" Molzahn and Sheilds (Molzahn and Sheilds 2008, p. 25) mention an exercise that was conducted as part of a research interest group that pertains to spirituality and health. Members of the group were asked to define spirituality and comment on its importance. Many in the group struggled with writing and talking about its meaning. They were concerned that aspects of spirituality were missing in what they wrote and suggested that they could not be articulated. The illustration shows that there is an unspokenness inherent in spirituality. Scholars noted that the notion of spirituality is still under construction; it has, and inevitably always will be, a social construction (Murgia et al. 2020, p. 1328). Further, many cultures and religious traditions use language about spirituality in different and sometimes contradictory ways, adding to the complexity of respectfully discussing the topic with everyone. The fear of offending others likely contributes as well to people's reluctance to open discussion of spiritual issues. This led many to avoid talking about spirituality at all costs. For some, it is often considered taboo to openly talk about spirituality outside of one's own religious or spiritual community.

Terms such as spirituality and religion are also, oftentimes, used interchangeably even by researchers on this topic. There seems to be confusion in the utilization of such terms. One of the reasons is that most research on spirituality has been measured through the lens of religion and by religious interventions (Victor and Treschuk 2020, p. 109). The same confusion is usually expressed by students at GMU at the start of the semester. Many would think that spirituality and religion are one and the same, which implies that if one is not religious-however one defines religiousness, then the person is not spiritual either and vice versa.

In spite of ambivalence, students ${ }^{2}$ at GMU break the silence and confusion about spirituality by defining and describing it as it pertains to human experience and how it was taught to them-or the absence thereof, growing up either in their respective households or in schools and communities where they belong. The results of the study suggest the following theme-categories: (1) spirituality is an abstract reality, which is difficult to define; (2) spirituality is a moral compass, giving direction and meaning to people; and (3) spirituality and religion are not the same, but they are interrelated. The article concludes that for university students who participated in the study, spirituality is a fluid concept that is unique from person to person; and recommends that academic institutions need to integrate into curricula mechanisms that would facilitate the spiritual growth and development of students.

Interviewers found that while respondents had their own perceptions of spirituality, including religious beliefs and practices, there were also common threads in their responses to interviews. This led the interviewers to believe that spirituality, while not often talked about in daily discourse, is present in Mason students' lives. 


\section{Scope}

As mentioned above, this article highlights three theme-categories on spirituality based on a study that Mason students conducted with their fellow students as respondents. By using a qualitative approach, this article utilizes students' perspectives in articulating our discussion on spirituality, and explores at the end how academic institutions can provide open spaces and initiate conversations with their students, to nurture and help everyone develop spiritually, especially in settings where students have expressed a high level of interest in spiritual matters? Proponents ${ }^{3}$ of the study decided to use interviews (in-person, via text, phone, and email) in gathering information. The study was exploratory in nature as the following section explains. The problem that proponents wanted to investigate was the complexity in defining or describing spirituality especially from the perspectives of their peers.

\section{Methodology}

In this article, eighty-eight graduate and undergraduate students from GMU took part in a research project spearheaded by the Spirituality and Conflict Transformation class (6 credits) (Fuertes 2021, Course syllabus). The goal of the project was for the class to explore Mason students' definitions and conceptions of spirituality in hopes to understand further the nature and dynamics of spirituality through the lens of their fellow students.

The class of twenty-five students was divided into four groups. Each group was charged to interview, at least, twenty-students: Group 1 (22 interviews), Group 2 (20 interviews), Group 3 (24 interviews), and Group 4 (22 interviews) totaling eighty-eight the number of Mason students who participated in the study. For consistency, all groups asked the same open-ended questions during interviews: "How would you define or describe spirituality?" and "What made you come up with such an answer?" Such open-ended questions gave the respondents the opportunity to answer the questions based on where they came from and what they brought to the conversation. By asking such questions, the interviewers were able to identify key patterns and commonalities, while also noting the uniqueness of each response. Follow-up questions that relate spirituality to religion and vice versa, including manifestations of spirituality in people's lives were also asked.

In this study, the interviewers themselves came from diversified backgrounds with varying beliefs and religious affiliations. Additionally, the pool of respondents did not discriminate against sex, race, ethnicity, or age as presented in the data, but rather reflected the same diversity that GMU is known for. As mentioned above, the interviewers utilized a variety of methods to conduct the interviews, namely: in-person interviews, via text, phone, email, and social media. These were utilized for accessibility, time constraints, and to allow interviewees to respond in their most comfortable way as the interviewers recognized that the topic of spirituality can be difficult to speak about.

Notably, of the eighty-eight students pooled, $25 \%$ (22 individuals) preferred not to identify themselves with any religious affiliation, if at all, while 22\% (19 individuals) identified as atheists, agnostics, and/or irreligious. The same 22.7\% (19 individuals) self-identified as Christians. Around twenty percent (18 individuals) claimed they were religious, but without any religious affiliation, and 11\% (10 individuals) responded, "not sure." The religious diversity among the respondents allows for multiple perspectives, alluding to the fluidity of spirituality as defined within the Mason community as the results of the study suggest. In terms of spirituality, seventy-five percent of the respondents (66 individuals) considered themselves to be spiritual, while 21.6\% (19 individuals) claimed they were not spiritual, and $3.4 \%$ ( 3 individuals) were unsure at the time of the interview.

\section{Qualitative Data Analysis}

The study used qualitative data analysis. Interviewers came up with the above themecategories by generating statement summaries based on responses, including narratives that were collated from the interviews. Statement (or narrative) summaries, according to Maxwell and Miller, can take the form of thumbnail sketches of such statements or 
narratives, capturing a few pertinent highlights. Statement or narrative summaries provide the interviewers with specific themes that respondents in this project highlight, which are based on their ideas and experiences of spirituality. With statement or narrative summaries, interviewers identified patterns and other issues surrounding respondents' ideas and experiences of spirituality (Maxwell and Miller 2007). Indeed, the type of relationship used in data analysis is based on similarity or common threads. As Maxwell and Miller explain, similarity-based relations involve resemblances or common features, which when applied to data analysis take the form of specific themes and emerging patterns that interviewers were able to generate based on the data gathered. This data is then grouped by category, examined, and compared, both within and between categories. Such analytical strategies that focus on relationships of similarity are referred to as categorizing strategies (Maxwell and Miller 2007).

\section{Discussion}

\subsection{Spirituality Is an Abstract Reality, Which Is Difficult to Define}

Right at the beginning of the semester, this was before the class embarked on this project, students were asked as part of leveling off, "What comes to mind when you hear the word, 'spirituality?" Several answers were given such as having a sense of purpose, or something that relates to God, a higher being, or to yoga and meditation, including personal values; some claimed spirituality is tied to religion while others did not believe it's the case nor does spirituality relate to God or a divine being. A few referred spirituality as a belief in signs from the universe like astrology. Some argued spirituality is about religious symbols and rituals, while a few thought of spirituality as finding your core or digging deep into your being in order to find the meaning of your existence and purpose in life.

During the debriefing, the class was asked if they could come up with one statement that best captures the richness of their answers as indicated above, immediately almost everybody said that spirituality is an abstract reality, which is difficult to define or describe in a sentence. They said that there is no single definition or description that embodies the totality of what spirituality is, based on what transpired during the discussion.

Interestingly, such a response from the class reflects a degree of vagueness on the part of those who were interviewed for this project in answering the question but resonates with many authors when it comes to their conceptions and articulations of spirituality. Respondents expressed difficulty articulating fully their thoughts on spirituality. They claimed they know about spirituality. However, when asked to define or describe it, they struggled. One can assert spirituality is a word that everyone uses but nobody knows what anyone means by it (Nita 2019, p. 1607). As McGinn (McGinn 1993, p. 1) puts it, "spirituality is like obscenity; we may not know how to define it, yet we know it when we see it, and the 'fickleness' of academics inability to provide precise definitions has never prevented people from practicing it."

Defining spirituality has always been difficult (Harris 2007; Palmer 1997). As Taggart (Taggart 2001, p. 325) aptly puts it, “ ... it is the nature of spirituality to be elusive. While some ... want to be clearer on what it is, ... others strongly resist giving it a definition at all, knowing the tyrannical, restrictive power of definitions." Empirically speaking, the area of spirituality was quite undefined, before the 1980s. There were hardly any concepts that possessed widely accepted definitions (Ratnakar and Nair 2012, p. 2). Even for scientificallyminded researchers, spirituality had not really been an area of interest until the turn of the century. Many asked why spirituality was normally not treated as a scientific variable and why its relationship with other accepted psychological variables had not been extensively studied and statistically analyzed. They agreed that it was quite difficult to define, let alone measure spirituality (Ratnakar and Nair 2012, p. 1). However, in this study, the differing answers of Mason students indicated the richness and the multi-faceted nature of spirituality, which ignited a degree of interest and curiosity among many in the class. This made the discussion even more interesting and challenging at the same time. 
To some extent, spirituality is often misunderstood because of its deep association with religion (Victor and Treschuk 2020, p. 108), which makes it confusing. Yet, it is abstract and subjective and is different from religion and faith. As mentioned above, the literature shows no consensus on the concepts of spirituality while there is a partial consensus for religiousness (Vitorino et al. 2018).

The etymology of the word, spirituality, is from the Latin word spiritus, which means to blow or to breathe, and has come to mean that which gives life to the soul (Victor and Treschuk 2020, p. 108). Spirituality is a deep part of being human (Mountain 2007, p. 193). This explains why when asked to elaborate their answers, respondents shared their assumptions about spirituality as (1) an interconnection of something beyond ourselves and connecting something within ourselves. This can be a connection to God, a deity, the environment, or the natural world; and (2) the practice of a certain religion or outside an organized religious system or with a blending of different religious and cultural traditions. In other words, spirituality is the outward manifestation or expression of one's beliefs, religious or not. This brings our discussion to the next theme-category that respondents identified.

\subsection{Spirituality Is a Moral Compass, Giving Direction and Meaning to Life}

There is something about spirituality that provides a sense of meaning to people's lives, whether respondents of the study consider themselves religious or not. One of the most notable findings from a survey that UCLA administered in fall 2004 to 112,232 entering first-year college students at 236 campuses nationwide is that today's incoming students place significant personal emphasis on matters related to the interior dimensions of their lives (Lindholm 2007, p. 10). In the study, roughly two-thirds believe that it is "essential" or "very important" that their undergraduate experience enhance their selfunderstanding, prepare them for responsible citizenship, and support their emotional development (Lindholm 2007, p. 10). In essence, students are searching for deeper meaning in their lives, looking for ways to cultivate their inner self, seeking to be compassionate and charitable, and striving to determine what they think and feel about the many issues confronting them and their communities (Lindholm 2007, p. 10).

Respondents believed spirituality provides a clearer sense of direction, especially those who are mindful about their spirituality. What was interesting to note during interviews was that those who did not consider themselves spiritual were open to the possibility that perhaps they are spiritual after all in the sense that they feel something beyond physical or material within which they believe has helped to sustain them every day. "Perhaps it's my spirituality that keeps me going," said some of the respondents. In terms of what spirituality provides students with, one of the interviewing groups reported that Mason students believed spirituality is what sustains them; it's what provides them both the inspiration and determination in life to continue living and never give up.

Many adults, according to Tisdell (Tisdell 2003, p. 31), indicate that spirituality is a major organizing principle that guides their life choices, including choices of lovers and intimate friends and the kinds of work that they see as their vocation as they make meaning of their life experience and connectedness. Individuals in this context do what they feel called to do that is, what gives their lives meaning in terms of who they are, what they are doing, and the contributions they are making (Vaill 1996, p. 218).

Respondents elaborated their response by indicating that spirituality provides them a way to review and interpret the events in life, to make sense out of them, and to come to terms with and develop a sense of integrity about who they are as human beings. As Baker (Baker 2003, p. 22) puts it, "The person who successfully synthesizes his or her life and shows the highest degree of involvement, be it inner or outer, will also be the person who has the best potential for perceiving a good quality of life and for being satisfied with life." The meaning they get from the religious practice, for example, through their personal prayer life, or through quiet meditation, enables them to cope with life's problems and challenges, including pain and suffering (Baker 2003, p. 22). 
Respondents believed spirituality provides a sense of direction and purpose in life. As one group shared its findings, "Spirituality is what makes us feel good; it gives us a sense of direction and helps make meaning of what's happening around us; spirituality makes us feel more whole and one with ourselves. In other words, it is a reality check for accountability/responsibility for what happened and how to react."

Devotion to different forms of ethical or philosophical values such as a strong conviction to a political party, for example, or a belief in uniting generations or ethnicities, or striving to save the environment-any of these, according to Baker (Baker 2003, p. 55), can provide an organizing principle that motivates people. As they pursue their passions whether it be through religion, philosophy, the arts, music, nature, and so on, they build a history of involvement, the meaning of which they can evaluate and synthesize for themselves (Baker 2003, p. 55). They can also pass along to future generations the values, morals, knowledge, history, and wisdom that they have acquired (Baker 2003, p. 55).

In addition, respondents mentioned mindfulness as an element of this theme-category. "Spirituality involves being mindful and connects with your present emotions", they said. One respondent who practices Buddhism shared that his faith encourages him to be 'mindful' that is, to be more aware of his thoughts and actions, and urges him to address injustices and inequalities in the world. He considers his social involvement an expression of his spirituality, giving him meaning and purpose in life. As one interviewing group reported, "Students having a sense of meaning and purpose in life through spirituality are able to also set up life's goals. It gives them the capacity to somehow transcend their predicament and discover an adequate guiding truth." This finding embodies what Nietzsche implies when he said, "He who has a why to live can bear with almost any how" (Allport 1984, p. 10).

Meaning-making, as another element of spirituality that respondents highlighted, is a central theme of existentialism. "Life is not primarily a quest for pleasure ... or a quest for power ... but a quest for meaning" (Kushner 2006, p. xii). For the respondents, meaningmaking is essential to living a purposeful and fulfilling life, which lies at the heart of spirituality. In his article, Eaude (Eaude 2009, p. 189) references Hyde's subtitle, 'searching for meaning and connectedness', who captures three central elements of the discourse on children's spirituality, namely: First, there is the sense of search, of trying to make sense of existential questions—such as Who am I?, Where do I fit in?, Why am I here?-related to identity, place and purpose. This involves a process of making meaning, which is the second element of the discourse. Here, Eaude makes reference to John Hull who, thinking about the process of his going blind, wrote 'The most important thing in life is not happiness but meaning. Happiness is the product of chains of accidents that tend towards our wellbeing. Blindness does not make me happy. I did not choose it, nor was it inflicted upon me. Nevertheless, as an accidental event it could become meaningful' (Eaude 2009, p. 190). One of Hull's key insights is that meaning is always conferred retrospectively (Eaude 2009, p. 190). So, meaning, according to Eaude, is constructed in response to, and to make sense of, experience, whether or not within a specific, explicit framework such as that of religious faith. The third aspect of Hyde's subtitle is 'connectedness' (Eaude 2009, p. 190).

Viktor Frank, the author of Mans's Search for Meaning and father of Logotherapy, mentions three possible sources for meaning, all of which embody the discourse of spirituality as conceptualized by the respondents in the study: (1) in work or by doing something significant, (2) in love or by caring for another person, and (3) in courage during difficult times (Kushner 2006, p. x). Exemplifying these sources of meaning according to Frankl, may be done by utilizing religious and spiritual coping strategies, given that respondents use religion, spirituality, or faith to deal with stress and the negative consequences of life's problems (Ribeiro et al. 2020). Such utilization of religious and spiritual coping strategies leads to positive psychological states of peace, healing, contentment, hope, and joy (Del Castillo 2021, p. e254). Coping strategies that respondents identified include the following:

- Creating something purposeful to your soul; 
- Finding a connection to something that excites you and makes you look forward to;

- Surrounding yourself with those who love and cherish you;

- Goal-setting and regular meditation, and reflection;

- Listening to music and writing daily journals to record events in life;

- Being with nature;

- Helping people in need;

- Altruism or learned-helpfulness through volunteerism;

- Practicing your religion;

- Self-care;

- Being passionate about something;

- Being your most authentic self;

- Appreciating people you meet every day.

Meaning-making in the context of what Mason students mentioned above suggests an element of an unstructured, personalized, and natural occurring phenomenon where a person seeks closeness and/or connectedness between him/herself and a higher power or purpose (Bożek et al. 2020). It can be the diverse ways people answer the heart's longing to be connected with the largeness of life-a longing that animates love and work (Palmer 1997, p. 16). One interviewing group of students put it thoughtfully, based on their findings,

Spirituality can be a guide to get through rough times; it is something that is constant and grounds you; it can help you find what makes you happy; it is a source of hope for a better future; it can inspire you to feel more empowered; spirituality often comes with gratitude.

\subsection{Spirituality and Religion Are Not the Same, but They Are Interrelated}

Of the total number of respondents interviewed for the study, fifty-eight or $65.9 \%$ indicated that religion and spirituality are different but interrelated; while twenty-five or $28.4 \%$ believed both are somehow the same, and five or $5.7 \%$ were unsure. A Hindu participant stated, "Hinduism is all about spirituality so there is no difference between the two. Both are linked together." She said further that if someone is spiritual, that person is religious at the same time. Other respondents noted that the two can be interrelated, [but] they did acknowledge that people can have one without having the other. The primary divergence being that "spirituality is a tool used to comprehend large concepts in life while religion can be the vessel to get there," they said.

Within the last couple of decades, contemporary spirituality has, indeed, been the subject of some debate in the field of Religious Studies, particularly regarding the distinction between religion and contemporary spirituality in relation to secularization, the privatization of religion, and changes to social life (Nita 2019, pp. 1606-7). Although scholars from other disciplines seem to be writing about 'spirituality' in a more matter-of-factly fashion, however, as soon as they attempt to define 'spirituality' or propose 'spiritual guidelines' they stumble across such questions as 'what is spirituality actually?' and (if we cannot be sure of what it is) 'what does it do'? An unspoken divide is represented by whether scholars, tacitly or explicitly, believe that 'spirituality' does in fact denote something real, that can be explored, or not (Nita 2019, pp. 1606-7). This makes differentiating spirituality from religion difficult. The overlap and distinctions between religion and spirituality are complex (Kao et al. 2020, p. 43). Therefore, people try and take the easy path and use them as synonyms, thereby complicating things further. As Ratnakar and Nair (Ratnakar and Nair 2012, p. 4) explain, many of the negativities of organized religion get rubbed off on spirituality, as many times the two concepts are vaguely clubbed together.

To reiterate, spirituality is a more personal belief and experience of a divine spirit or higher purpose, about how we construct meaning, and what we individually and communally experience and attend to and honor as the sacred in our lives (Tisdell 2003, p. 29). Spirituality can be conceived as being outside of the religious traditions, which usually involves an awareness of interconnectedness with transcendence (Mountain 2007, 
p. 193). Conversely, religion, according to Victor and Treschuk (Victor and Treschuk 2020, p. 107) is, oftentimes, defined as a personal set or institutionalized system of religious attitudes, beliefs, and practices, including the service or worship of God or the supernatural. Such religious practices may include religious service attendance, community involvement, or affiliation (Kao et al. 2020, p. 43).

In Spiritual Revolution: Why Religion is Giving Way to Spirituality, authors Heelas and Woodhead (Heelas and Woodhead 2005, p. 7) distinguish religion from spirituality by juxtaposing the beliefs and practices of a Christian congregation to that of a network of spiritual seekers. They contend that while religion was concerned with objective roles, duties, and obligations, spirituality was concurrent with a 'subjective turn in the modern culture' and is mainly predicated on inner, subjective life. From this standpoint, according to the authors, the spiritual revolution can be said to take place when 'holistic' activities having to do with subjective-life spirituality attract more people than do 'congregational' activities having to do with life as religion. In this context, spirituality is often understood as a loose, floating compound of beliefs and practices divorced from religious traditions, predicated on the self (Nita 2019, p. 1609). Therefore, spirituality may or may not involve religion (Victor and Treschuk 2020, p. 109); however, religion may be an expression of spirituality to some, and vice versa (Hawthorne and Gordon 2020, p. 147).

For many respondents, their sense of spirituality is being linked to religion. They defined spirituality as a characteristic of religion; like a measure of how in line with religion an individual is. "Mindful of my religious teachings and duties, I live my life as an outward manifestation of my spirituality," said one respondent. Victor and Treschuk (Victor and Treschuk 2020, p. 109) explain that spirituality can be expressed through various religious practices such as rituals and living by certain religious values. Even those who do not consider themselves religious can have a spiritual dimension. Respondents who did not consider themselves religious, for example, revealed that they do conduct spiritual practices on a daily basis, unbeknownst to them before. In other words, a person often inherits religion but makes the conscious choice to practice spirituality by seeking answers about the self, universe, and meaning of life (Zakrzewski 2013, p. 2).

Ellison (Baker 2003, p. 51), who developed a spiritual well-being scale, regards spirituality as the 'integrative power or force' that influences, and is influenced by, the psyche and the physical body. Ellison believes that people are psycho-spiritual beings who are 'integrated and integrative systems with overlapping, but partly distinct subsystems.' The spiritual dimension is one of the subsystems as well as the integrating force for all the subsystems. Accordingly, spirituality is the connecting force, or integrating power, that unifies all of life (Baker 2003, p. 51). For example, we look at ourselves according to who we are in terms of our personality, our memory, or our imagination. We define ourselves in terms of our community, our relationships with our family, friends and neighbors, the way we care for one another, the way we appreciate our environment, whether we surround ourselves with music, or nature, or whether we regard religion in terms of a transcended life force, or as some truth or perfection with God as a part of all these dimensions of spirituality. Everything is tied together by spirituality; it is the force that gives meaning to everything, and that which makes sense out of things (Baker 2003, p. 51).

\section{Conclusions and Recommendations}

Results of the study suggest that spirituality is a fluid concept to articulate among students in higher education, which resonates with most of the existing literature on this topic. Nevertheless, the article is able to come up with common threads that connect the respondents' thoughts and assumptions together in terms of theme-categories. A central statement in this study is clear: spirituality is a basic element of who we are as human beings. The question is, "Can conceptions of spirituality be considered 'universal'"? Proponents of the study indicate that spirituality is subjective, which is unique from person to person. Therefore, it is important that students in higher education be given spaces to articulate openly their conceptions of spirituality and effect meaningful conversations 
around the topic. Since it appears that there are no universal definitions of spirituality, respectful listening to one another within the context of open dialogue needs to take place toward holistic growth and development. Here, academic institutions need to spearhead open spaces and initiate conversations with their students, to nurture and help everyone develop spiritually. The question is, "Are our institutions ready for this collective undertaking?".

\section{What Does This Study Mean for Higher Education?}

It is apparent that for students in higher education, spirituality shapes the perspectives brought into educational settings and the values placed at the center of academic pursuits (Lindholm 2007, p. 11). Spirituality aids the process of developing the whole student and affects learning while shaping perspectives and academic pursuits (Triana et al. 2020, p. 5). The challenge facing colleges and universities is when they do nothing if not little either to help students explore (further) such issues or to support their search in the realm of values and beliefs, even though students express a high level of interest in spiritual matters (Triana et al. 2020, p. 10). In this context, one approach to strengthening (and nurturing students' sense of) spirituality in higher education is to move from the inside to the outside, to work out from the core of our (human) experiences (Chickering 2006, p. 4).

Academic institutions need to integrate into curricula mechanisms that provide students, in particular, avenues to express themselves creatively be it inside the classroom or via campus activities. This can be through music, art, nature, or exploring great individuals whose lives have inspired and challenged them to be the best they can be in life. Such avenues give students opportunities to give something to the world through self and collective expressions using their talents, skills, and abilities in the things that they do, including their everyday interaction with people around them, including the natural world. At George Mason University, for example, students, including faculty and staff, can avail themselves of the programs and services of the Center for the Advancement of Well-being (Center for the Advancement of Well-Being 2021). The center with its slogan, "Creating a World that's Thriving Together," catalyzes human well-being by promoting the science and practices leading to a life of vitality, purpose, resilience, and engagement (https:/ / wellbeing.gmu.edu/, 12 September 2021). As an interdisciplinary center at Mason, the staff are dedicated to helping individuals and organizations thrive in a world of complexity and uncertainty (https:/ / wellbeing.gmu.edu/, 12 September 2021).

Another approach to integrating spirituality in higher education is by providing students experiential learning opportunities to expand cultural fluency, critical and reflecting thinking, wellbeing, interpersonal relationship, and global understanding competencies, to name a few. Spirituality as presented above is partly about experiencing what the universe has to offer. This is how meaning-making unfolds that is, being open to receiving what the world and the people around us extend to us. Forms of experiential learning may include local community immersion or integration where students live with the local people, experience their cultures, and be part of the community's interpersonal and social interactions, which forge deep bonding and meaningful, sustainable relationships. This can be done through voluntary service, internships, study abroad, and cross-cultural exchange programs, among others.

Two leading offices with phenomenal programs at Mason that promote and implement experiential learning include the Social Action \& Integrative Learning (SAIL) and the Global Education Office (GEO). Housed within the School of Integrative Studies (SIS), SAIL is an evolving community of Mason students, faculty, administrators, alumni, and community partners who are active and passionate collaborators in effecting positive social change (SAIL 2021). SAIL fosters integrative, innovative, and experiential learning opportunities such as alternative breaks, field studies, leadership through community engagement, community-based learning, and seeds of change, to name a few. Such opportunities are on campus, regional, and global that educate and activate towards a more equitable, just, nonviolent, and sustainable world (SAIL 2021). On the other hand, GEO strives to make 
global learning experiences a reality for all Mason students and faculty by facilitating international learning opportunities through a diverse array of study abroad programs that engage students and faculty in meaningful and life-changing experiences (GEO 2021). In addition to these programs, the experiential learning component of education is embedded in all courses at SIS and in other academic units in the university. One example is the class that spearheaded this study, INTS 315 Spirituality and Conflict Resolution (6 credits), where students examine the dimensions of spirituality as they relate to a range of activities, including peacemaking efforts in large scale conflicts, conflicts within faith communities, and interpersonal disputes (Fuertes 2021).

When students are able to relate what they are learning in school to their respective communities and the world in general, and vice versa-this will help cultivate and nurture their interests and aspirations, thereby, enabling them to develop meaning and purpose in life; by doing so, as Zakrzewski (Zakrzewski 2013, p. 5) points out, when students bring these topics up, understanding that spirituality may be developmental and fluid in terms of definitions, teachers can respond in ways that are both respectful and affirming to students growth process.

Author Contributions: Investigation: A.F.; Conceptualization: A.F. and K.D. All authors have read and agreed to the published version of the manuscript.

Funding: This research received no funding.

Institutional Review Board Statement: Not applicable.

Informed Consent Statement: Not applicable.

Conflicts of Interest: The authors declare no conflict of interest.

\section{Notes}

In this article, 'George Mason University,' 'Mason', and 'GMU' are used interchangeably.

In this article, 'Mason students' and 'respondents' are used interchangeably.

In this article, 'proponents' and 'interviewers' are used interchangeably.

\section{References}

Allport, Gordon. 1984. Foreword. In Victor Frankl's Man's Search for Meaning. New York: Simon and Schuster, pp. 9-13.

Baker, David C. 2003. Studies of the inner life: The impact of spirituality on quality of life. Quality of Life Research 12: 51-57. [CrossRef] [PubMed]

Bożek, Agnieszka, Mateusz Blukacz, and Paweł F. Nowak. 2020. The Relationship Between Spirituality, Health-Related Behavior, and Psychological Well-Being. Frontiers in Psychology. [CrossRef]

Center for the Advancement of Well-Being. 2021. George Mason University. Available online: https://wellbeing.gmu.edu/ (accessed on 12 September 2021).

Chickering, Arthur. 2006. Authenticity and Spirituality in Higher Education: My Orientation. Journal of College E Character 7: 1. [CrossRef]

Del Castillo, Fides A. 2021. Health, spirituality and Covid-19: Themes and insights. Journal of Public Health 43: e254-e255. [CrossRef] [PubMed]

Eaude, Tony. 2009. Happiness, emotional well-being and mental health—What has children's spirituality to offer? International Journal of Children's Spirituality 14: 185-96. [CrossRef]

Fuertes, Al. 2021. INTS 315 Spirituality and Conflict Transformation (6 Credits). Course Syllabus.

Global Education Office (GEO). 2021. George Mason University. Available online: https://studyabroad.gmu.edu/ (accessed on 12 September 2021).

Harris, Kathleen I. 2007. Re-conceptualizing spirituality in the light of educating young children. International Journal of Children's Spirituality 12: 263-75. [CrossRef]

Hawthorne, Dawn, and Shirley Gordon. 2020. The Invisibility of Spiritual Nursing Care in Clinical Practice. Journal of Holistic Nursing 38: 147-55. [CrossRef] [PubMed]

Heelas, Paul, and Linda Woodhead. 2005. The Spiritual Revolution: Why Religion Is Giving Way to Spirituality. Oxford: Wiley-Blackwell.

Kao, Larkin Elderon, Christopher C. H. Cook, and John R. Peteet. 2020. Spirituality and mental health. Journal for the Study of Spirituality 10: 42-54. [CrossRef]

Kushner, Harold. 2006. Foreword. In Victor Frankl's Man's Search for Meaning. Boston: Beacon Press, pp. ix-xii. 
Lindholm, Jennifer A. 2007. Spirituality in the Academy: Reintegrating Our Lives and the Lives of Our Students. About Campus: Enriching the Student Learning Experience 12: 10-17. [CrossRef]

Maxwell, Joseph A., and Barbara A. Miller. 2007. Categorizing and Connecting as Components of Qualitative data Analysis. Manuscript. In Handbook of Emergent Methods. Edited by P. Leavy and S. Hesse-Biber. New York: Guilford Press.

McGinn, Bernard. 1993. The letter and the spirit: Spirituality as an academic discipline. Christian Spirituality Bulletin 1: 1-10.

Molzahn, Anita, and Laurene Sheilds. 2008. Why is it so hard to talk about Spirituality? The Canadian Nurse 104: 25-29. [PubMed]

Mountain, Vivienne. 2007. Educational contexts for the development od children's spirituality: Exploring the use of imagination. International Journal of Children's Spirituality 12: 191-205. [CrossRef]

Murgia, Carla, Alessandro Stievano, Gennaro Rocco, and Ippolito Notarnicola. 2020. Spirituality in nursing: A concept analysis. Nursing Ethics 27: 1327-43. [CrossRef] [PubMed]

Nita, Maria. 2019. Spirituality in Health Studies: Competing Spiritualities and the Elevated Status of Mindfulness. Journal of Religion and Health 58: 1605-18. [CrossRef] [PubMed]

Palmer, Parker J. 1997. The Heart of a Teacher Identity and Integrity in Teaching. Change: The Magazine of Higher Learning $29: 14-21$. [CrossRef]

Ratnakar, Rajesh, and Shreekumar Nair. 2012. A Review of Scientific Research on Spirituality. Business Perspectives and Research 1: 1-12. [CrossRef]

Ribeiro, Marcus Renato Castro, Damiano Rodolfo Furlan, Fabio Nasri, Giancarlo Lucchetti, and Ricardo Marujo. 2020. The role of spirituality in the COVID-19 pandemic: A spiritual hotline project. Journal of Public Health 855-56. [CrossRef]

Social Action and Integrative Learning (SAIL). 2021. George Mason University. Available online: https://sail.gmu.edu/program (accessed on 12 September 2021).

Taggart, Geoff. 2001. Nurturing Spirituality: A rationale for holistic education. International Journal of Children's Spirituality 6: 325-39. [CrossRef]

Tisdell, Elizabeth J. 2003. Exploring Spirituality and Culture in Adult and Higher Education. San Francisco: Jossey-Bass.

Triana, Claudia, Jeanett Castellanos, and Alberta M. Gloria. 2020. Cultivating Success for Latinx Undergraduates: Integrating Cultural Spirituality within Higher Education. About Campus: Enriching the Student Learning Experience 4-9. [CrossRef]

US News \& World Report Best Colleges. 2021. Available online: https:/ /www.usnews.com/best-colleges (accessed on 4 July 2021).

Vaill, Peter. 1996. Learning as a Way of Being: Strategies for Survival in a World of Permanent White Water, 1st ed. San Francisco: Jossey-Bass.

Victor, Chitra G. Paul, and Judith Treschuk. 2020. Critical Literature Review on the Definition Clarity of the Concept of Faith, Religion, and Spirituality. Journal of Holistic Nursing 38: 107-13. [CrossRef] [PubMed]

Vitorino, Luciano Magalhaes, Frederico Camelo Leao, Giancarlo Lucchetti, Homero Vallada, Mario Fernando, and Prieto Peres. 2018. The association between spirituality and religiousness and mental health. Scientific Reports. November 22. Available online: https: / / www.nature.com/articles/s41598-018-35380-w (accessed on 25 July 2021).

Zakrzewski, Vicki. 2013. The Case for Discussing Spirituality in Schools. Greater Good Magazine 1-5. Available online: https: / / greatergood.berkeley.edu/article/item/how_to_discuss_spirituality_in_school (accessed on 9 July 2021). 